\title{
Architecture_MPS
}

\section{Framing the Real: Lefèbvre and Neo-Realist Cinematic Space as Practice}

David Brancaleone ${ }^{1}$

How to cite: Brancaleone, D. 'Framing the Real: Lefèbvre and Neo-Realist Cinematic Space as Practice.' Architecture_MPS, 2014, 5(1): 4, pp. 1-22. DOI: https://doi.org/10.14324/111.444.amps.2014v5i4.001.

Published: 01 October 2014

\section{Peer Review:}

This article has been peer reviewed through the journal's standard Editorial double blind peer review.

\section{Copyright:}

(C) 2014, The Author(s). This is an Open Access article distributed under the terms of the Creative Commons Attribution License (CC-BY) 2.0 https://creativecommons.org/licenses/by/2.0/, which permits re-use, distribution and reproduction in any medium, provided the original author and source are credited • DOI: https://doi.org/10.14324/111.444.amps.2014v5i4.001

\section{Open Access:}

Architecture_MPS is a peer-reviewed open access journal. 


\title{
Title: Framing the Real: Lefèbvre and Neo- Realist Cinematic Space as Practice
}

\author{
David Brancaleone
}

Architecture_media_politics_society. vol.5, no.4.

October 2014

Affiliation: Limerick School of Art and Design, Ireland

\begin{abstract}
:
In 1945 Roberto Rossellini's Neo-realist Rome, Open City set in motion an approach to cinema and its representation of real life - and by extension real spaces - that was to have international significance in film theory and practice. However, the re-use of the real spaces of the city, and elsewhere, as film sets in Neo-realist film offered (and offers) more than an influential aesthetic and set of cinematic theories. Through Neo-realism, it can be argued that we gain access to a cinematic relational and multidimensional space that is not made from built sets, but by filming the built environment. On the one hand, this space allows us to "notice" the contradictions around us in our cities and, by extension, the societies that have produced those cities, while on the other, allows us to see the spatial practices operative in the production and maintenance of those contradictions.
\end{abstract}

In setting out a template for understanding the spatial practices of Neo-realism through the work of Henri Lefèbvre, this paper opens its films, and those produced today in its wake, to a spatio-political reading of contemporary relevance. We will suggest that the rupturing of divisions between real spaces and the spaces of film locations, as well the blurring of the difference between real life and performed actions for the camera that underlies much of the central importance of Neo-realism, echoes the arguments of Lefèbvre with regard the social production of space. In doing so, we will suggest that film potentially had, and still has, a vital role to play in a critique of contemporary capitalist spatial practices. 


\section{Title: Framing the Real: Lefèbvre and Neo- Realist Cinematic Space as Practice}

\section{Authors: David Brancaleone}

Architecture_media_politics_society. vol.5, no.4.

October 2014

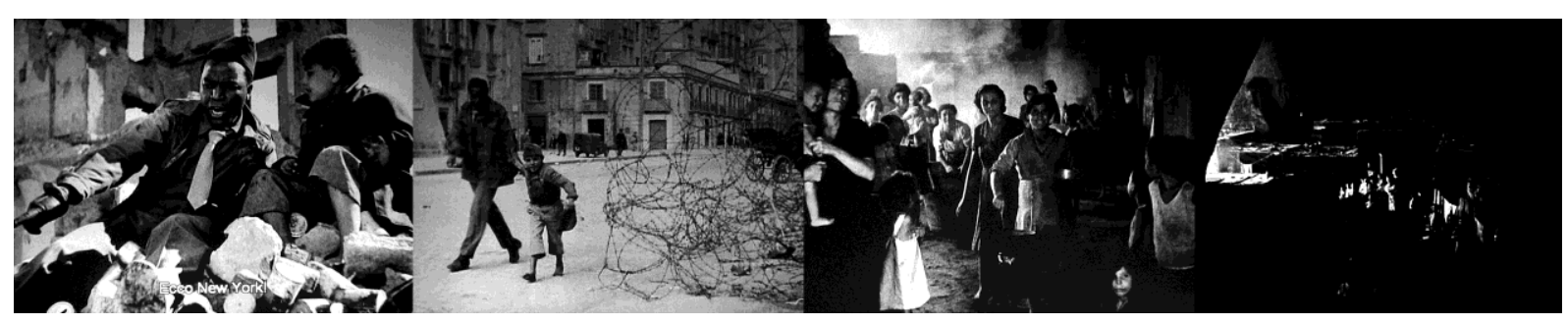

Fig. 1. Rossellini's Paisà (1946) goes where "transient life manifests itself most conspicuously". The viewer is made to wander through Naples in a fiction. Its mimesis enables the Gl to describe to Pasquale the skyscrapers of New York, while sitting on a pile of rubble. Their seemingly erratic trajectory confronts the viewer with the real city. The wandering ceases when faced with a crowd of displaced people actually living in the caves of Mergellina who become fleeting screen presences in the Naples episode's shocking denouement.

\section{Introduction}

In 1945 Roberto Rossellini's Neo-realist Rome, Open City set in motion an approach to cinema and its representation of real life - and by extension real spaces - that was to have international significance in film theory and practice. ${ }^{1}$ However, the re-use of the real spaces of the city, and elsewhere, as film sets in Neo-realist film offered (and offers) more than an influential aesthetic and set of cinematic theories. ${ }^{2}$ Through Neo-realism, it can be argued that we gain access to a cinematic relational and multi-dimensional space that is not made from built sets, but by filming the built environment. On the one hand, this space allows us to "notice" the contradictions around us in our cities and, by extension, the societies that have produced those cities, while on the other, allows us to see the spatial practices operative in the production and maintenance of those contradictions.

In setting out a template for understanding the spatial practices of Neo-realism through the work of Henri Lefèbvre, this paper opens its films, and those produced today in its wake, to a spatio-political reading of contemporary relevance. We will suggest that the rupturing of divisions between real spaces and the spaces of film locations, as well the blurring of the difference between real life and performed actions for the camera that underlies much of the central importance of Neo-realism, echoes the arguments of Lefèbvre with regard the 
social production of space. In doing so, we will suggest that film potentially had, and still has, a vital role to play in a critique of contemporary capitalist spatial practices.

\section{Filmic context}

Rome, Open City (1945) can be defined as the inaugural feature film about $a$ city which attempted to historicize the contemporary moment, and namely, a specific time in post-war Italy. ${ }^{3}$ Despite its inconsistencies, Rome, Open City marks an historical break, because it established a new problematic within mainstream cinema, bringing the contemporary event into filmmaking. ${ }^{4}$ In the immediate post-war period of Europe, the film presented an urban landscape of destruction which meant that , unsurprisingly, ruins became a metaphor for suffering, poverty and war - a metaphor repeated in Rossellini's masterly Germany Year Zero (1948). ${ }^{5}$ Until recently, this metaphor of ruins tended to define Neo-realism, detracting from its ground-breaking film practice and exploration of cinematic space. ${ }^{6}$ As David Forgacs has subsequently shown, the film was also a demonstration in how to represent the complexities of urban space. ${ }^{7}$

One such complexity was the very architecture of the city of Rome itself. Fascism had exploited imperial Classicism to validate its own totalitarian regime and, as Mark Shiel has shown, the Neo-realist city countered this. It no longer celebrated the city's iconic architectural past, that the Fascists had appropriated for their own totalitarian ends, as scenic spectacle, but rather, it rejected this neo-classical architecture. ${ }^{8}$ In Neo-realism, the old choreography of symbols of the past became a floating signifier haunting contemporary space and, at most, appeared in dialectical opposition to the contradictions of capitalist development. Another such complexity is, of course, our understanding of 'realism' itself. In most debates about the realism of Neo-realism since the 1960s, the concept of 'the real' has been reduced to an adequation of the screen image to the material world. ${ }^{9}$ Such critique tends to point out inconsistencies in doing away with sets, studios and professional actors; on criticising its re-enactments, on making distinctions based on this narrow understanding of its form of realism. ${ }^{10}$ As Forgacs underlines, the complexities of representing urban space are clearly manifold.

Cesare Zavattini - Neo-realism's principal theorist and the screenwriter of film classics such as Bicycle Thieves (1948) Miracle in Milan (1951) and Umberto D (1952) - contended in this regard that Neo-realism was also a "working hypothesis", "a tendency", "a development of a certain kind of cinema". Sharing Antonio Gramsci's idea of a new culture with a new art to match it, where "new" is a code word for political, anti-fascist and openly committed to social change, Zavattini's arguments are central to the arguments put forward here. ${ }^{11}$ If, in examining these issues around Neo-realism, we broaden our view from Italy to the rest of Europe and beyond, as some scholars are doing today, a new set of theories can be called upon and a new pattern emerges. We can begin to see, for example, that Neo-realism's operating principle is nothing less than a cinematic spatial practice that echoes Henri Lefèbvre's ideas in The Production of Space (1991). We can also see the continued adoption of key aspects of Neo-realism, within different cinematic and cultural spatial practices. ${ }^{12}$ Ultimately, Neorealism's aesthetic has outlived both the post-war era, the French New Wave and even Dogme 95 and the social issues it raises through its use of real actions and real spaces, remains relevant in the twenty-first century. ${ }^{13}$

In recent years the Neo-realist "tendency" can be found in films in which the dialectics of documentary and fiction combine to sharpen the image. Examples include Gianni Amelio's Ladro di bambini (1992), Mario Martone's Terra di Mezzo (1997) and Giorgio Diritti's L'Uomo che Verrà (2009). ${ }^{14}$ In Vittorio De Seta's Lettere 
dal Sahara (2004) the boundaries of the European city are challenged outright. De Seta does this by establishing a dialogue with Senegalese culture uprooted into the adoptive city, and learning to see familiar urban spaces through the eyes of "clandestine" immigrants. The European city is rejected in favour of home, when the protagonist returns by choice to his more civilised Senegalese village or our view of it is expanded by the ways in which uneven geographical development intrudes into its spaces, producing a new cinematic urban space that corresponds to the contemporary world. ${ }^{15}$

Another example is Jafir Panahi's Offside (2006) which challenges the religiously motivated segregation of women fans from football matches through enactment, making rebellion into a physical space, almost in real time, through the experience of a girl who acts as a witness and whose body is denied access and confined. The entire film revolves around her confinement and the solidarity she generates with other female fans. Wang Xiao Shai's Beijing Bicycle (2002) defines two Beijings in the one city which comes across as two-faced, depending on which class you belong to in a supposedly classless society. Finally, Abbas Kiarostami's Ten (2005) combines the reality of urban everyday life with scripting, based on direct observation. Set in Teheran, the city becomes a synecdoche: the inside of a car travelling through it, driven by a young woman and mother whose conversation with the people to whom she gives a lift, producing an urban relational space in such a cooped up space. ${ }^{16}$ All of these films employ spatial practices recognisable from the neo-realist tradition to relate acutely important contemporary issues.

\section{Kracauer and Lefèvbre - linking life and the environment}

Reducing Neo-realism to a national phenomenon or a post-war episode, soon overtaken by events, results in the failure to consider the importance and continued significance of the shift it achieved: "the decision to go out into the street". ${ }^{17}$ On the reductivist account, historical Neo-realist location shooting has been seen as just an expedient, forced by material post-war shortages. ${ }^{18}$ Even André Bazin, who was no reductivist, minimised the significance of rejecting the artificial studio in favour of outdoor filming, by suggesting it was a question of the aesthetic suitability of the Italian cityscape in which space was conceived more like a theatrical stage. ${ }^{19}$

In contrast to this, Siegfried Kracauer places much emphasis on how Neo-realist films captured street life and what that achieved, ie. the conveying of the continuum of the real: ${ }^{20}$

"Sensitivity to this flow seems to be an inherent feature of Italian neorealism. To

Rossellini, De Sica, and Fellini life that concerns us is essentially the kind of life which

only the camera is capable of revealing.

Their films time and again probe into significant aspects of it."21

The street is:

"That province of reality where transient life manifests itself most conspicuously;" the place of "fleeting impressions", where "the accidental prevails over the providential, and happenings in the nature of unexpected incidents are all but the rule." 22 
Kracauer departs from Bazin then, by emphasising time and space and in linking time to space in a comparison with story-based films of American classic cinema. Kracauer compared the Neo-realist space-time continuum to the structure of tragedy given that tragedy, he argued, presupposes an ordered cosmos. ${ }^{23}$ Kracauer singles out Zavattini in particular, for championing a direct approach to the dramatic sequences of "environmental life" 24 and in doing so, suggests an importance that would outlast the national phenomenon of a specific post-war episode.

Although Kracauer clearly underlines the significance of Neo-realism in spatial terms, it is Henri Lefèbvre's ground-breaking The Production of Space that makes it possible to reconsider Neo-realism in terms of a mostly urban cinematic spatial practice, and most significantly, a political one, rather than as a mere representation of space. ${ }^{25}$ Lefèbvre's crucial move was to take an abstract concept and ground it in practice by relating space to time, and thus historicizing it [space]. He overturns Hegel's renewed idealisation of space as an abstract entity and restores Marx's insistence on historical time as revolutionary time. Consequently, he links self to environment, on the grounds that lived space involves an ingrained politics of space. ${ }^{26}$

Lefèbvre's attack on the very idea that space is an a priori category, to be considered in isolation as an abstract entity, is essential here. ${ }^{27}$ In alienating self from environment, Lefèbvre argues that the Descartesian dichotomy ${ }^{28}$ had effectively excluded the real space of social practice from philosophy and aesthetics ${ }^{29}$ and that, consequently, space has become understood as an "empty container" in which "people, actions, situations" have been separated from what they do within it and with it. ${ }^{30}$ Lefèbvre shows that such a notion of a neutral space is flawed, and that far from being neutral within a capitalist society, space is divided. ${ }^{31}$

In his seminal text, Lefèbvre rejects the notion of these ideal spaces, cities or buildings being conceived, designed and built by an architect as pure artistic creations without any interference from external material forces. ${ }^{32}$ Lefèbvre defines all spaces as "social practices". ${ }^{33}$ This, the alienated and idealist spaces (divorced from the urban fabric of lives and activities) of Haussmann's Paris under Napoleon III, or any number of the Imperial and later Fascist projects across Italy are rethought as "social practices" actively responding to underlying conditions: attempts to repress urban class struggle in the case of Haussmann or town planning designed to incorporate or replicate symbolic features of antiquity to validate Fascist Rome and dictatorial rule.

Lefèbvre's critique however, was not focused on the ancient city, but rather the contemporary capitalist city in development throughout the period of Neo-realist film, up until the student and worker revolt in Paris in $1968 .^{34}$ The underlying forces of mass production in every major aspect of capitalism was seen as underlying the emergence of the modernist city - consequently read as little more than the inevitable manifestation of the socioproductive forces at work under state capitalism. Such schemes are thus seen as the large scale application of cost effective manufacturing and construction techniques designed to facilitate economic growth and profit; their status as a response to the need to house large numbers of people being just another coincidental component of their social practice.

Crucially, Lefèbvre argued that there is a human potential to subvert and overcome the imposing restrictions and formulations of capitalism and its particular spatial forms. As Michael Gardiner shows, Lefèbvre's rejection of philosophical idealism extended beyond spatial conceptualisations to notions of everyday life. ${ }^{35}$ In Gardiner's 
reading of Lefèbvre, his view of the subdivided modern city of CIAM and its isolated zones for play, living and working etc, reflected capitalism's separation of all human activities. ${ }^{36}$ Central to the resistance of capitalism then is not only a new conceptualisation of space, but also a view of the everyday as a site for breaking down barriers between work, play and other aspects of our daily activities. Therefore, it is only when the link between space and the material world is made that the contradictions of social space can emerge. ${ }^{37}$ But it is only when the concomitant divisions in life are broken down that we can begin to resist. Seen in the context of Lefèbvre then, by going out into the city, Neo-realism helps discover and exposes what Lefèbvre calls "the relations of inclusion and exclusion" within space and, by extension, life itself. ${ }^{38}$

\section{Neo-realism as spatial practice}

The film screen has been theorised as an autonomous world in itself which divides the unrepresentable real from the imaginary. ${ }^{39}$ In the context of the ideas of Kracauer and Lefèbvre however, it can also be understood and theorised as a threshold. In this this screen-as-threshold conceptualisation, to break out of the screen frame is to cross that threshold and the Neo-realist combining of documentary with fiction can be seen as one aspect of it. ${ }^{40}$ The barrier between screen and real (or between space as it appears on the screen and space off the screen) need not be so rigid. It can be broken down after all; Neo-realism can be seen as doing so in pioneering two kinds of interrelated spatial practice, one on screen, the other off screen as we shall see.

To elaborate, this reaching out from fictional city to lived city constitutes a form of political intervention in filmic and spatial practice. On screen, the dialectic of fiction and documentary is there from the beginning. Thus the major filmmakers Visconti, Rossellini, Antonioni, Lizzani, Maselli, De Santis (and later Fellini) all made documentaries, as well as fiction. ${ }^{41}$ Indeed, the inaugural fictional feature film of the new Italian cinema (Rome, Open City) was shown in Rome in October 1945, at the same festival in which the documentary Days of Glory was premiered on the last day. This was about the Italian Resistance with mostly indexical shots of that time and of the actual dramatic events that occurred immediately after the end of the war (for example the exhuming of bodies in a massacre of civilians in caves just outside Rome). ${ }^{42}$ The two films have in common Marcello Pagliero, a main character (Manfredi) in Rossellini's Rome, Open City, and one of the filmmakers who made Days of Glory. In both films, but in different ways, cinema embraces the real world of contemporary Italian society. As is known, Rome, Open City includes characters standing in for historic figures and events around which the film was built: the priest Don Morosini (Aldo Fabrizi) and Teresa Gullace (Anna Magnani). Despite the myth-making aspect, probably inevitable and certainly desirable after the war, the film includes documentary evidence of the city after the war, and in this respect, is no different from Rossellini's Paisà (1946) or his Germany Year Zero (1948).

Whereas post-war Italian documentaries were soon to be censored out of existence, by depriving filmmakers seeking to make serious films about the contemporary of any funding, to some extent, films such as Rome, Open City subsumed from the documentary tradition the inclusion of the real and the real city which meant that the presentation of the contradictions of the modern city and, in these cases, its internal divisions between affluence and extreme poverty are brought to the fore. In doing so, it can be argued that Neo-realist spatial practice reveals the complex reality of the dialectical city and works through a new kind of fiction, inscribed within and 
confronting itself with everyday life. ${ }^{43}$ It describes and surveys, maps and measures, determines and defines space, thereby bringing it to visibility through the camera. The backdrop city comes to life when it is met and traversed by Neo-realist characters, an ideal example of which is Antonio and Bruno in Bicycle Thieves (1948) ${ }^{44}$ or Dot Johnson and Pasquale in the Naples episode of Rossellini's Paisà. ${ }^{45}$

By contrast, in Luigi Zampa's L'onorevole Angelina (1947) the vague concept of what a built environment is becomes tangible not through wandering, but human agency, when a neighbourhood strengthened by solidarity and sense of community rejects the status quo of shortages and double standards. The screen frames the real Pietralata, a crumbling working-class suburb built under Fascism, and re-enacts a contemporary event - the occupation led by a local woman of apartment blocks still under construction after the flood of February 1947, and the failure to distribute food supplies to the district. ${ }^{46}$
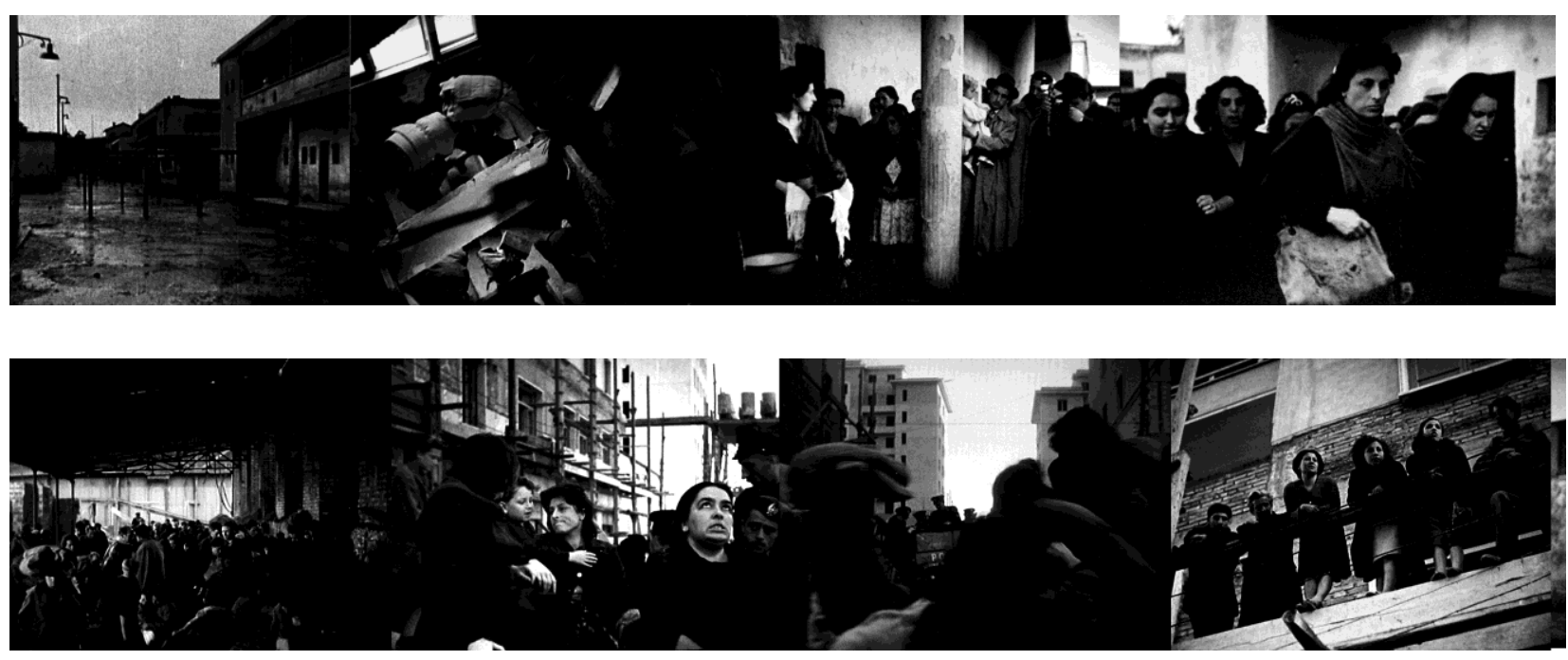

Fig. 2. L'onorevole Angelina (1947) (above) is a dramatic re-enactment on location, in which "location" refers to the actual places where the rebellion had occurred only a few months earlier. The film was released the same year.

\section{Spatial and political praxis in the films of Cesare Zavattini}

Nowhere is this new approach to the city more visible than in a cluster of films scripted or coordinated by Zavattini and made between 1951 and 1963. They develop the enquiry aspect of Neo-realism in a different direction to Bicycle Thieves (1948) but, on the whole, are entirely consistent with his version of Neo-realism, as theorised in "Some Ideas about Cinema" and earlier writings. For example, from Rome's current events, Zavattini takes the news story of Termini, Ore Undici (1951) in which 200 women, waiting in a building for a job interview fall from the stairs, and some to their deaths. The off screen research for the film involved producing an in-depth dossier which included interviews of the surviving women, interviews about working conditions and how it was the norm for them to be at the receiving end of sexual harassment, not to mention door-to-door interviews with local residents. ${ }^{47}$ The attempt to reflect reality, no matter how harsh, underlay not 
only the preparation, but also the filming and direction. It was directed by Peppe De Santis, a member of the Italian Communist Party who fought with the anti-German Resistance in Rome in the Second World War.

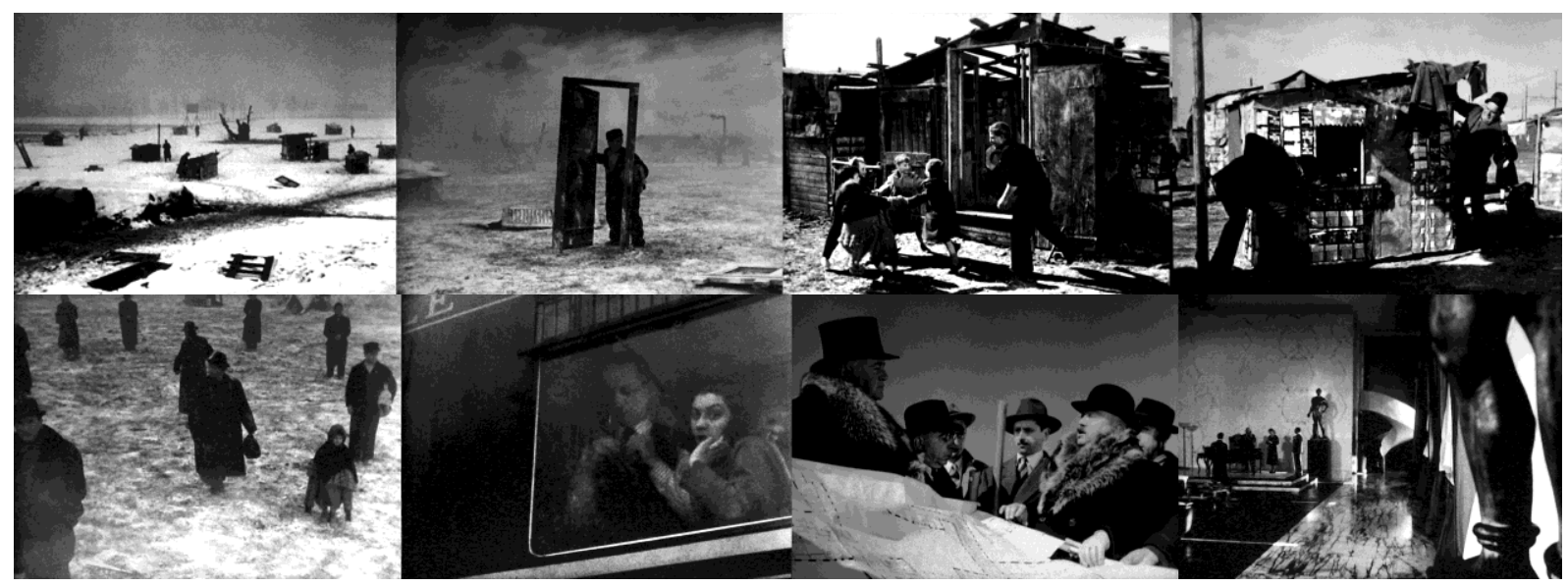

Fig. 3. Miracle in Milan (1951). From chaos of unrelated shacks built in the same space to order and planning (top far left). From a warm interior train compartment, wealthy travellers look on to the random, haphazard space of destitution and homelessness (bottom row). Moving a shack to align it with the street (top far right). The space of power is reminiscent of Fascist and Nazi architectural spaces (precious marble floors and walls combined with vast scale) and sculpture (Nazi Arno Becker lookalikes) (bottom row).

Made the same year, Miracle in Milan (1951), based on Zavattini's book Totò il Buono (1943), presents the city very differently. ${ }^{48}$ Although cloaked in the form of a fable, the book and the film point to a divided city, dealt with people living rough in the periphery of Milan and, in the making of the film, the director employed nonprofessionals (genuine homeless people) to add to the realism of the portrayal. The aimless wandering of the protagonist Totò in search of somewhere to stay soon comes to an end when he meets the shambolic individuals living near the railway line. He takes the lead to organise a new, entirely self-reliant community and, as a result, the deserted land by the railway becomes a functional squat; a communal living space with its amenities, public spaces and streets named as multiplication tables so children could learn to count - for example, STREET 8 × $9=$ 72.

Through its observations of everyday life, combined with flights of fancy, its spatial practice demonstrated an alternative model to competitive and individualist capitalism based on solidarity. "Above all, there's the kind of solidarity that springs from sharing suffering and deprivation; and intelligence has made up for the lack of means", reads Zavattini's film treatment. ${ }^{49}$ The social objectives underlying the presentation of life and the spaces of life in this film then, are clear. It was only due its fable-like character that the story survived censorship under the Fascist regime, and the film later managed to survive the censorship of the Christian Democrats' in the years after its release.

The key to the interviews, background research, in-depth location visits, both in Zavattini's fiction and documentary films, is his theorised spatial practice, rooted in urban space, of "shadowing". Replacing wandering as an operative principle, it is also foundational in cinema history and represents a dialogical approach to people's lives and their spaces. It can be seen at work in Love in The City (1953); We Women (1953); The Roof (1956); Mysteries of Rome (1963) and The Newsreel of Peace (1963). This materialist embracing of the real, in 
all its manifestations, was according to Zavattini, more than humanism. In "Some Ideas on Cinema" and "Thesis on Neo-realism" he describes it thus:

"What interests me is the drama of the situations you actually meet, not the ones you imagine. Make poetry out of the real: exercise your poetic sensibility in situ; you need to leave your room and take your body out to meet other people and make an effort to understand them." [...] "In this [analytical] approach, there is a powerful dynamic of attention to things: a desire for understanding, empathy, participation, co-habitation." "This is what I call a cinema of encounter". 50

In Love in The City (1953) Rome's cityscape becomes a cinematic map and an embodied site of Zavattini's "shadowing" (pedinamento). It encapsulates a Neo-realist approach to the city, as a lived space in which to intervene and its attention is focussed on what lies beyond its closed doors and façades. ${ }^{51}$ This pioneering sixepisode inquiry film is prefaced by tiny sketches which take place across the city at different times and serve to map out the city in time and different locations. ${ }^{52}$ All the specific references to time of day and location in Rome are treated as the fact-based coordinates of the chosen theme and generate a map in the flash-film sequence that determines spatio-temporal markers for the city - a form of "cognitive map". ${ }^{53}$ For example, Via Gallia and Via Trasimeno 19, are mapped at $4.30 \mathrm{pm}$ and $7.30 \mathrm{pm}$, respectively. The six episodes directed by major Neo-realist filmmakers deal with real people and their real lives: prostitution, suicide and a single mother who abandons her baby, amongst other things. In each one, the camera breaks the separation between the public and the private, bringing the real and the fictional expectations of the medium.

The Roof (1956), based on Zavattini's scenario and screenplay, features the true story of newly-weds seeking a place to live. Made long after L'onorevole Angelina (1947), it highlighted the fact that the problem of housing shortages had not gone away. ${ }^{54}$ The couple find out that it is possible to squat on communal land and succeed in doing so, by constructing a small dwelling overnight which would be legalized, provided the roof was erected by the morning. In a telling sequence, a builders' lorry takes the couple past the Colosseum and up the Via dei Fori Imperiali, a deliberate cinematic journey, combining in one travelling shot the icon of Imperial Rome with the symbol of Fascist neo-imperialism, an avenue that was built during Mussolini's dictatorship, in a reminder of Fascist urban planning (an entire district was demolished to make way for it). This is how the regime justified through the scale of spectacle its colonial expansionism and through mapping, by creating a presumed continuity of empire. ${ }^{55}$ By juxtaposing the ideal Fascist city with the real city of cramped living conditions and poverty, and setting the slum dwellings in juxtaposition to new construction for the middle and upper class, The Roof's social argument was clear.

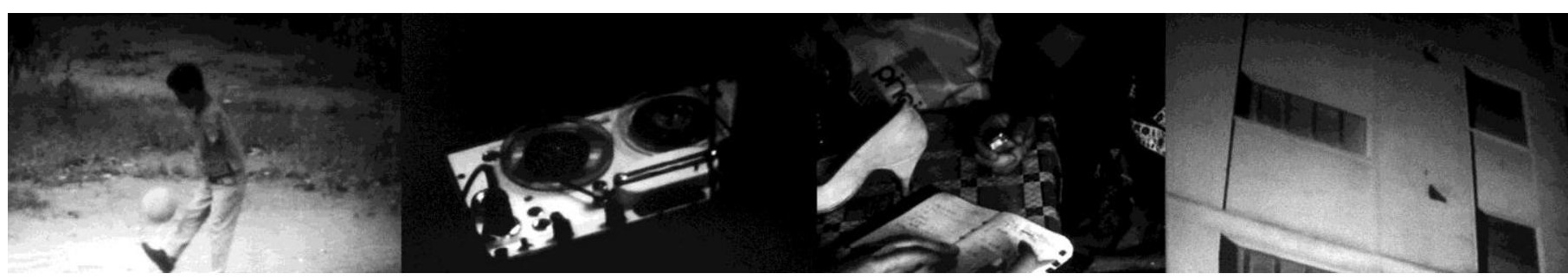

Fig. 4. Mysteries of Rome (1963) (above). The voice-over's "here" (qui) points to the lived spaces. 
The city of Mysteries of Rome (1963) could not be more specific, mapping a day in the life of the city through its contradictions at the height of the economic boom, by filming and interviewing those excluded from the new affluence of the period. ${ }^{56}$ Mysteries of Rome takes Zavattini's shadowing of people and places from Love in The City which had been made years before cinéma vérité. Cinematic space develops outwards into a mosaic structure, by accretion, replacing the abstract, aerial city with the city as lived space, with an opening shot, from a plane flying over the city that cuts to the lived spaces of children playing football in an orphanage, mutilated by wartime bombs; to the sounds and fear of giving birth; to a locum visit to a poor household; to the notorious Via Tasso, remembered for having once been the Gestapo HQ in occupied Rome, accompanied by voice-over recalling how neighbours remembered the sounds of torture leaking out of the holes in the walls; to blood donors selling their blood for cash out of sheer poverty; to the tales of woe of exploited copyists; to casual road construction workers waiting to be hired on the street corner and showing the interviewer their injuries caused by lack of health and safety measures on site; to the developing world through photos of destitution at the United Nations' offices in Rome. Taken as a whole, these interviews and sorties into real everyday situations, occurring in the very sites and buildings, produce a network of interrelated spaces of the lived city that populate or embody the mapping of spaces made by the opening aerial sequence. The closing aerial shot produces a cinematic allegory, by travelling over the same spaces which the viewer sees in a layered way, as prospect or aerial perspective, but also remembered by the viewer as the actual space produced by the people who live there, with a final voice-over singling out each time with the word "here" (qui) the lived spaces obscured by such a distant view.

\section{Conclusion}

In all these films the presentation of real life is set in very real spaces that not only follow the spatio-temporal and thematic traits of Neo-realism, but which also set a template that remains in evidence today; films such as Ladro di bambini (1992), Terra di Mezzo (1997), Offside (2006), L'Uomo che Verrà (2009) and Lettere dal Sahara (2004), to cite just a few contemporary examples. Beyond this however, what this paper has attempted to underline is that each of these films, in its fusion of real space with the setting of filmic action; in its correlation of real lives with on screen depiction; and in its conflation of the represented filmic protagonist and the real life protagonist, almost unavoidably invites parallels with the ideas and arguments of Henri Lefèbvre. There is the same refusal to portray space as isolated from its use: whether it be the employment of the homeless to depict the homeless in Miracle in Milan (1951); the shadowing techniques used in the investigative Love in The City (1953); the replication of a real life experience in The Roof (1956), populating the abstract city with the lived city and its events in Mysteries of Rome (1963); or the spatial practice of real locations in all of them. Luxurious spaces are not isolated from poorer locations, but placed in dialectical contradiction; the mediatic or artistic representation of a city local is not seen as isolated from the forces that produced it - either economically or materially; and people's real lives blur with their filmic representation and/or presentation.

As a result, it is possible to see in Neo-realism, a filmic enactment and a cinematic practice, in line with Lefèbvre's ideas on space as social practice rooted in everyday life. There is the same rejection of what Lefèbvre defined as abstract space - the supposedly isolated artistic creations of the artist-architect. There is also the same 
reaction against the artificial divisions in everyday life that separate work, from leisure, and everyday actions from supposedly isolated important ones. In the wake of Lefèbvre, David Harvey distinguishes between relative space and the absolute space and going as far as to "name" relational space, one charting the relationship between the object and the influences bearing upon it. Even in a fiction about the real and confronting the real, individuals are seen not to exist in a vacuum, but in a relation with the urban reality surrounding them, by engaging with it, changing it, mapping it by wandering through it, escaping it, showing it up by their witnessing, enacting its constraints. ${ }^{57}$ This is how the legacy and 'afterlife' (the Warburghian nachleben) of Neo-realism then, obliges us to confront the social, political and economic forces that shape our lives and the spatial conditions and containers of those lives in well-established, if perhaps, under-examined ways, through film. Consequently, these films and the more recent ones discussed earlier, sharing their same characteristics, demonstrate the potential of cinema as a medium and a realm of possibility, only partially realised then, as Zavattini often pointed out, in feature films (as well as documentaries), to play a vital role in a critique of contemporary capitalist spatial practices. ${ }^{58}$ 


\begin{abstract}
${ }^{1}$ My gratitude to Arturo Zavattini and Prof. Mino Argentieri for permission to translate into English Zavattini' texts, Citto Maselli, Max Le Cain, editor of Experimental Conversations, Ronan Madden of University College Cork, Fiona Woods, colleague at LSAD and all the staff at the Archivio Audiovisivo del Movimento Operaio e Democratico (AAMOD) Paolo Scarnati, Claudio Olivieri, Letizia Cortini, to Graham Cairns and the anonymous reviewer for advice, guidance, practical help and valuable comments.

${ }^{2}$ This paper is not concerned with cinematic mediations in which space is understood only as a fictional space or a backdrop to a story. Nor is it a study of how we might imagine cities. It considers certain cinematic cities being an embodied space. From the perspective of imagined cities, cf. James Donald, Imagining The Modern City (London: Athlone Press, 1999). Donald's city is an imaginary city, "abstractly conceptual" Donald, Imagining The City, x. While Donald recognises the value of Lefèbvre's The Production of Space, he concentrates on the urban imaginary, arguing that "symbolic constructs have material consequences". Donald, Imagining The City, 27. The essays collected in David Clarke's The Cinematic City (London and New York, Routledge, 1997) make an important contribution to the exploration of metaphorical or allegorical representations of the city and, in some cases, intersections with the off-screen city, suggesting that the lived city may be perceived through its shared screen representation.

${ }^{3}$ Even if we accept that it cannot be more than a "filmed simulacrum of occupied Rome", as Forcas would have it. Strictly speaking, "simulacrum", in Plato's original definition refers to that which does not exist. The modern revisiting of it in Deleuze, Derrida or Baudrillard, on the other hand, departs from Plato in considering its inexistence a legitimate entity. Whereas, contemporary Rome is the referent for the near contemporary Rome of 1944, Open City, itself a cinematic rendering, a mimesis (see below, footnote 9). Cf. David Forgacs, Rome Open
\end{abstract} City (London: British Film Institute, 2000), 35.

${ }^{4}$ It seems important to note that Neo-realism marked for cinema something greater than generic humanism, a "space of hope". (On "spaces of hope", cf. David Harvey, Spaces of Hope, (Edinburgh: Edinburgh University Press, 2000). Harvey uses the figure of the architect as the starting point to imagining the construction of a space of hope, to then suggest that we are all architects of life. This seems especially apposite in the context of constructing filmic space, or practising lived space, as Lefèbvre would have it. Cf. Harvey, Spaces of Hope, 201). In national politics, it coincides with a specific historical time of insurrection, declared by Italian partisans on 25 April 1945. This was the second revolutionary moment for the Left in Italy in the twentieth century (the first was the workers' insurrectionary strikes in the North of Italy, between 1919-1920, paralleled in Germany with the Berlin Spartacist revolt of 1919, and in Ireland with the Easter Rising of 1916). Then, in 1948, when the Centre Right took control of the state, the hegemony of capital and the logic of profit was reinstated and revolutionary aims scotched, coinciding with the establishment of post fascist politics, renewal of the Church-State conciliation or Fascist Lateran Pact signed by Mussolini and the Vatican in 1929, and the new dawn of Right wing McCarthyism, spreading from North America across Western Europe and the repression of the social in cinema, through direct and indirect censorship. Yet for Antoine de Baecque, cinema meets history (which, from his postmodern view, is equated with the Shoah), only in 1955, with Alain Resnais's documentary Night and Fog. That is when he believes an alternative cinema history began, leading to the French New Wave. Cf. "The Cinematographic Forms of History" in Antoine De Baecque. Camera Historica. The Century in Cinema. Trans. Ninon Vinsonneau and Jonathan Magidoff (New York: Columbia University Press, 2012), 2-29. Ruberto and Wilson, "Introduction" in Laura E. Ruberto and Kristi M. Wilson eds. Italian Neorealism and Global Cinema (Detroit: Wayne State University, 2007), 5.

${ }^{5}$ In this film the death of a child by suicide in post-war Berlin, is allegorical: signifying the despair at the collapse (ruins) of the democratic project begun during the Resistance with the alliance of progressive forces and the persistence of Nazism in post-war Europe. See: Gian Piero Brunetta, Il cinema neorealista italiano. Da 'Roma città aperta' a 'I soliti ignoti' (Bari: Editori Laterza, 2009), 64. De-Nazification never took place in Italy where the prewar Fascist burocracy and state apparatus was entirely restored after the war.

${ }^{6}$ Yet, the Neo-realist city is a space inflected differently from filmmaker to filmmaker; for example, picturing the parallel worlds of popular culture, or its traces, however ironic, as in Peppe De Santis's Bitter Rice (1949); the high culture of opera in how Luchino Visconti frames poverty in Sicily in La terrra trema (1948) or celebrating the stage as real or even criticising its very existence, (as in Federico Fellini's films); or making poetry, allegory, metaphor (in Rossellini or Pier Paolo Pasolini) and even fables or seeing the extraordinary in daily events (Zavattini).

${ }^{7}$ Forgacs, Rome Open City, 34. 
${ }^{8}$ For example, by linking St. Peter's (the Church) with a wide avenue (Via della Conciliazione "the avenue of reconciliation") to the rest of the secular city (the State), symbolising the Fascist Lateran Pact of 1929; or excavating the Ara Pacis (Augustus's monument) and moving it near Augustus' burial to strengthen the visibility of imperial Rome. Most recently, in Mark Shiel, "Cityscapes and Cinematic Space" in Peter Bondanella (ed.), The Italian Cinema Book (Basingstoke: Palgrave Macmillan, 2014), 84-91. Cf. also, Mark Shiel, Italian Neorealism. Rebuilding the Cinematic City (London: Wallflower Press, 2006) and Shiel, "Cinema and the City in History and in Theory" in Cinema and The City. Film and Urban Societies in a Global Context. Edited by Mark Shiel and Tony Fitzmaurice (Oxford and Malden Mass.: Blackwell, 2001).

${ }^{9}$ In this paper realism is not framed in terms of the extent to which these films fail to mirror reality or create an illusion of it. For, as Stephen Halliwell's The Aesthetics of Mimesis demonstrates, there has always been more to mimesis than the anti-realist turn since the 1960s has ever understood. Cf. Stephen Halliwell, The Aesthetics of Mimesis. Ancient Texts and Modern Problems (Princeton and Oxford: Princeton University Press, 2002). Antirealist philosophies and cultural histories have obscured and have been instrumental in obscuring what is at stake in mimesis and how certain episodes of mimesis stand out for contemporary filmmakers, having directly been revived in their practice.

${ }^{10}$ Colin MacCabe, "Bazin as Modernist" in Dudley Andrew and Hervé Joubert-Laurencin eds, Opening Bazin: Postwar Film Theory and Its Afterlife (Oxford: Oxford University Press, 2011), 66. Very recently, there have also been several attempts at a re-evaluation of Neo-realism, (albeit without ever questioning the consensus of understanding regarding mimesis), whether to investigate its relevance to contemporary film practice today or to consider its impact beyond the conventional framework of national cinema. After the ground-breaking 2007 anthology - Laura Ruberto and Kristin Wilson eds., Italian Neorealism and Global Cinema (Detroit: Wayne State University, 2007) - which showed the spread of Neo-realist ideas across continents and, more or less explicitly, questioning the physical, geo-political and temporal boundaries of the movement, the conference: "Ripensare il Neorealismo", cf. Antonio Vitti ed. Ripensare il neorealismo: cinema, letteratura, mondo (Pesaro: Metauro, 2008). This at the very least suggested it was time to rethink the movement, while Geoffrey Newell-Smith's Making Waves, published the same year, distinguishes between the first new wave and the subsequent new waves, which latter are considered heavily indebted to Neo-realism in adopting some of its main tenets, and his crucial essay of 2012, "From Realism to Neo-realism" in Theorizing World Cinema. Lúcia Nagib, Chris Perriam and Rajinder Dudrah eds (London and New York: I.B. Tauris, 2012), 147-159 which sides with the filmmaker who can be considered the first theorist of Neo-realism, Cesare Zavattini. Nowell-Smith overturns existing orthodoxies and reductive approaches that reduce it to a recipe, dictated by external circumstances (location shooting, non-professional actors, loose plot and so on).

${ }^{11}$ Cesare Zavattini interviewed by Tommaso Chiaretti, "Un Atto di Coraggio", Mondo Nuovo no. 49, December. 1960, in Neorealismo ecc., 224-229. Zavattini's reference to a "new culture" concerns the famous editorial in the very first issue of September 1945 of Il Politecnico, edited by Elio Vittorini which marked the "space of hope" for a radical break in culture and in politics. Unfortunately, it was limited to culture. De-Nazification never happened in Italy (as was the case in Austria). Thus, to give just one example, the Italian Fascist Party was reformed in 1946, albeit under the different name of Movimento Sociale Italiano (MSI). In his published diary, reflecting on the Conference of Parma which he had organised, Zavattini says: "'The point is not for one aesthetic to win out over another, but first and foremost to reaffirm the existence of Neo-realism and its potential for future development, and not in Italy alone. For any nation making cinema that is closely related to the real is Neo-realist. It participates in this vast movement of human empathy in ways most appropriate to itself, but with the sole purpose of getting to know the most serious problems of contemporary man. Neo-realism is by now the conscience of cinema." Zavattini, "Diario", Cinema Nuovo 27 (31 December 1953) in Zavattini, Neorealismo ecc., 131. Author's translation, here and throughout.

${ }^{12}$ Cf. Traverso in Ruberto and Wilson, Italian Neorealism and Global Cinema, 185. From this broader perspective, of relevance within the $21^{\text {st }}$ century and within world cinema, mainstream narratives about a national cinema or debates about, or debunking realism seem irrelevant.

${ }^{13}$ However unwittingly, Dogme nevertheless adopted Neo-realist principles which it identified with the French New Wave, closer to it in time. Cf. Richard Kelly, The Name of this Book is Dogme 95 (London: Faber and Faber, 2000). The Danish filmmakers Thomas Vintenberg and Lars von Trier, both graduates of the Danish film school wrote the Dogme95 Manifesto in March 1995. Theirs was a provocative gesture, seeking debate through shock tactics which succeeded in attracting a hostile press coverage. Kelly, The Name of this Book is Dogme 95, 2. As Kelly describes it, it was: "a radical movement in European cinema that ran an effective series of sorties against the operation of the 
US-directed mainstream". Kelly, The Name of this Book is Dogme 95, ix. For Kelly: "movies hadn't come very far in a hundred years. Roughly a century after the invention of cinema, the USA had succeeded in colonizing the global market in film. Fat, foolish, ruinously expensive and ideologically hateful, Hollywood movies were the world's dominant cultural product." Kelly, The Name of this Book is Dogme 95, 2. In world cinema, these have re-emerged. One could think of such principles or tendency with a spatial "meme", rejecting story-telling, in order to stop and observe. Cf. Richard Dawkins. The Selfish Gene (Oxford: Oxford University Press, 1989), 192. The reference to Dawkins is made to suggest the many ways in which a cultural practice, (in this case a spatial practice), ends up being adopted through different paths of transmission, ultimately, because it serves a need, despite the anti-realist agendas of mainstream critics.

${ }^{14}$ In L'Uomo che Verrà (2009) where, following the rediscovery of wartime archives, a Nazi massacre, censored from cultural representation in the 1940s and 1950s, is re-enacted, with an extreme attention to the facts, but mediated by fiction, comparable for its affective register to Rome, Open City and for the adoption of spoken dialect, as in Visconti's La terra trema (1948).

${ }^{15}$ Lettere dal Sahara invites the viewer to think about the kinds of problems created by "uneven geographic development", extending cinematic spatial practice from a city to a global dimension and reflecting recent migration patterns in Europe. Cf. David Harvey, A Brief History of Neoliberalism (Oxford: Oxford University Press, 2005), 65-119. The protagonist Assan is from Senegal. He is an "illegal" immigrant, shipwrecked, like so many in real life, on the Italian coast. In the story, this takes place off Lampedusa, an island near the Sicilian coast (in the very place where a year ago or so, many immigrants drowned). In less than six months, Assan works his way up the Italian peninsula, changing cities and jobs in Naples, Prato and Turin. Faced with one hardship after another, the worst being the attitudes he encounters, the climax is reached when Assan escapes death by lynching. At that point, having succeeded against all odds to integrate himself into Italian society, rather than remain in the "civilized" Europe which lynches fellows human beings, he opts to return to Cap Skiring in Senegal, the "backward" village, he is from, where he decides to tell his story. Cf. Mario Capello ed. La fatica delle mani. Scritti su Vittorio De Seta (Milan: Feltrinelli, 2008).

${ }^{16}$ In "Subject", one of the ten sections of his master class on filmmaking that is Ten on Ten (2003), Abbas Kiarostami explicitly cites the neorealist aesthetic put forward by Cesare Zavattini since the 1950s and tirelessly until his demise in 1989. While driving through the landscapes of his films, Kiarostami explains: "with its endless thirst for reality and truth, the kind of cinema I uphold never has its shortcomings of subject. As Zavattini says, the first person who passes by can be the subject of your film. The presence of millions of people with millions of problems is an unlimited source of subject matter for this kind of cinema. In my opinion, it will never come across a crisis, it will never be short of subjects." Abbas Kiarostami, Ten on Ten (2003). There are several texts in which Zavattini discusses the supposed "crisis of subjects". As early as 1942 or 1943, Zavattini in "The importance of Subjects" (L'importanza dei soggetti) states that: "I dare say that there is no such thing as a good or a bad subject, just as there is no sunset which contains in itself the virtues of a good painting. The subject, more or less honourably literary, is always on the other side of cinema and only becomes good cinema when it is no longer a subject". (Cesare Zavattini, "L'importanza dei soggetti" in Neorealismo ecc., 48 and "Basta coi soggetti", in Neorealismo ecc., 70-73, 71). Kiarostami also emphasises his debt to Zavattini's film aesthetics by discussing the Neo-realist idea of using non actors and explaining the rationale for this choice which comes across not as a stylistic recipe choice denoting a Bordwellian approach to film style, but an integral part of an aesthetic: "These individuals are selfcontained subjects and screenplays. As Zavattini said, there are often special and interesting enough people with a bulk of experiences which help them to create a more tangible, realistic and refined character. I must stress that we chose these non-actors because of their strong resemblance to the character we had imagined in the first place. As they are non-actors, it is unlikely, if not impossible, that they could successfully perform as another character. In other words, they play very well in one role and that is, as themselves." He gets to the heart of the Neo-realist aesthetic which he has entirely made his own, when he asks: "Is cinema about story or is it about reality?"

${ }^{17}$ Geoffrey Nowell-Smith, "From Realism to Neo-realism" in Theorizing World Cinema, edited by Lúcia Nagib, Chris Perriam and Rajinder Dudrah (London and New York, I.B. Tauris, 2012), 153. Siegfried Kracauer, Theory of Film. The Redemption of Physical Reality (Oxford: Oxford University Press, 1960), 72-73.

${ }^{18}$ One recent exception is Karl Schoonover's Brutal Vision. The Neorealist Body in Postwar Italian Cinema (Minneapolis and London: University of Minesota Press, 2012).

${ }^{19}$ Andrè Bazin, What is Cinema, vol. 1, trans. Hugh Gray (Berkeley: University of California Press, 1971), 28-29.

${ }^{20}$ Kracauer, Theory of Film, 71, 73.

${ }^{21}$ Kracauer, Theory of Film, 254. 
${ }^{22}$ Kracauer, Theory of Film, 255, 62.

${ }^{23}$ Kracauer, Theory of Film, 266.

${ }^{24}$ Kracauer, Theory of Film, 273.

${ }^{25}$ Mark Shiel's Italian Neorealism (2006) deals with the spatial dimension of Neo-realism in architectural terms, outlining the pre-war Fascist approach to the city in town planning and architecture, with its emphasis on symbolism of power. This paper also applies Lefèbvre to explore further the spatial dimension of Neo-realism. In the earlier volume Cinema and The City (2001), Shiel and co-editor Tony Fitzmaurice take Lefëbvre's concept of "spatialization" to frame the relation between cinema and the city in terms of a sociology of motion pictures and the role of cinema in the development of cities, as a "spatial", rather than a "textual" system, viewing the film in space and the film as space. Mark Shiel, "Cinema and the City in History and in Theory" in Mark Shiel and Tony Fitzmaurice eds., Cinema and The City. Film and Urban Societies in a Global Context (Oxford and Malden Mass.: Blackwell, 2001), 1-18, 3. Lefèbvre inaugurated "the spatial turn" in cultural studies which was taken up by his closest followers and students David Harvey and Manuel Castells and others. Fredric Jameson, also from a Marxist tradition (though not via Lefèbvre), applied Kevin Lynch's category of "cognitive mapping" from urban studies to cultural studies. Cf. Frederic Jameson, Postmodernism, or The Cultural Logic of Late Capitalism (London and New York: Verso, 1991) and Kevin Lynch, The Image of The City (Massachusetts: MIT Press, 1960). Lynch developed what he calls "a mental image of the city, through an empirical study of North American cities. Lynch, The Image of The City, 3. The impact of Lefëbvre's The Production of Space (1973) on the Anglophone academic world was delayed by a late translation. When it finally came out, it generated in architecture, urbanism and sociology especially, "the spatial turn" of these disciplines. However, space is a central concept in Lefèbvre as early as 1947, when the first of three volumes of Lefèbvre's The Critique of Everyday Life spanning thirty years was published. Since then, Lefëbvre's theory of space has been fleshed out by David Harvey and Manuel Castells to cope with uneven geographical development and the Web, sees a renewed relevance in a new cycle of political (and cultural) resistance to the system as we know it, with events in cities worldwide, from Tahrir Square to Plaza 15 Mayo and the Occupy movement.

${ }^{26}$ Lefèbvre, The Production of Space, 21. He follows Walter Benjamin's Theses of History, but without Benjamin's messianism. Cf. Walter Benjamin, "Theses on The Philosophy of History" in Illuminations edited by Hannah Arendt, translated by Harry Zohn (London: Fontana Press, 1992), 245-256. Emerging from a similar post-1968 moment of reflection, Alain Badiou's Theory of The Subject (1982) names the "outplace" the disempowered space, one marked by an exclusion, unrecognised and invisible, "place" as the ruling class's place which needs to be destroyed and "splace" which defined a displacement of ideas and actions, just as other similar revolts and revolutions (including the Arab revolution of 2011), as interruption of repetition or replication of the status quo.

Alain Badiou, The Theory of The Subject trans. Bruno Bosteels (London and New York: Continuum, 2009), 33, 130.

${ }^{27}$ Henri Lefêbvre. The Production of Space. Trans. Donald Nicholson-Smith (Oxford: Basil Blackwell, 1991), 12, 15 .

${ }^{28}$ This was the Cartesian schematization of reality into res cogitans (the reflecting human mind), pitted against res extensa (surrounding space, theorised in terms of inert surroundings. See: Lefèbvre, The Production of Space,40.

${ }^{29}$ Lefèbvre, The Production of Space, 15, 73.

${ }^{30}$ Lefèbvre, The Production of Space, 297.

${ }^{31}$ Lefèbvre, The Production of Space, 11, 292.

${ }^{32} \mathrm{Cf}$. Lefèbvre's arguments on representations of space and spatial representations. Cf. The Production of Space. 39-42

${ }^{33}$ Lefèbvre, The Production of Space, 8

${ }^{34}$ The Production of Space was inspired by the new spatial practices which took political conflict back into the streets and extended occupation to public buildings and to the street, in so modern a perspective as to be advanced, by comparison with Italian workerist theories and practices that still saw the factory as the one and only site of struggle against capitalism.

${ }^{35}$ Michael E. Gardiner, Critiques of Everyday Life (London and New York: Routledge), 75-77

${ }^{36}$ Cf. CIAM, La carta de Atenas, (1957) Buenos Aires: Editorial Contémpora and Eric Mumford, The CIAM Discourse on Urbanism, 1928-1960. Cambridge Mass.: MIT Press, 2000.

${ }^{37}$ Lefèbvre, The Production of Space, 307-308; 296, 10. Lefèbvre's approach distances him from twentieth-century structuralists and post-structuralists who still reduced social space to formal space, but for different reasons. Lefèbvre is Gramscian in his philosophy of space. For Gramsci writes: "Each of us changes himself, modifies himself to the extent that he changes and modifies the complex relations of which he is the heart. In this sense, the 
real philosopher is, and cannot be other than the politician, the active man who modifies his environment, understanding by environment the ensemble of relations which each of us enters to take part in." Antonio Gramsci, Selections from the Prison Notebooks, edited and translated by Quintin Hoare and Geoffrey Nowell-Smith (London: Lawrence and Wishart, 1971), 352.

${ }^{38}$ Lefèbvre, The Production of Space, 294.

${ }^{39}$ For the notion of the screen frame as entirely divorced from the world, cf. Richard Rushton, The Reality of Film. Theories of Filmic Reality (Manchester and New York: Manchester University Press, 2011). For Rushton, it serves only as a premiss to argue for the autonomy of the cinematic screen. The source of this idea is Stanley Cavell's. Cf. Stanley Cavell, The World Viewed. Reflections on The Ontology of Film, Enlarged Edition (Cambridge Mass., and London: Harvard University Press), 1979. But going back further, it is the theory of art for art's sake or the complete autonomy of art from the social. My argument goes in the opposite direction, towards a political cinema with a documentary-based spatial practice, no matter how fictional: and the working model for this comes to fruition with Neo-realism.

${ }^{40}$ On framing as editing or cropping from an image what surrounds it, cf. Trinh T. Minh-ha who invites us to consider what is left out of the frame. She makes the point that we need to frame the frame. Judith Butler explains this dynamic well: "to call the frame into question is to show that the frame never quite contained the scene it was meant to limn, that something was already outside, which made the very sense of the inside possible, recognizable." Part of the real is always excluded in representation. "Something exceeds the frame that troubles our sense of reality; in other words, something occurs that does not conform to our established understanding of things." Trinh T. Minh-ha, Framer Framed, New York: Routledge, 1992, cited in Judith Butler, Frames of War. When is Life Grievable? (London and New York: Verso, 2010), 8. We can ask the same question of the screen. More recently, David Harvey has adopted Lefèbvre's spatial distinctions, cf., for example, David Harvey, "Space as a Key Word" in: Spaces of Global Capitalism, Towards a Theory of Uneven Geographical Development, (London and New York: Verso, 2006), 119-148. Harvey distinguishes between absolute, relative and relational space, the last involving an interaction creating space.

${ }^{41}$ Off screen spatial practice involved valiant attempts at breaking hegemonic production and distribution channels and oppose governmental direct and indirect censorship; how in the 1940s and early 1950s there were mass street demonstrations by directors, actors, screenwriters and the personnel of the film industry, but also in other ways, by developing a film culture within the film clubs movement; and later, in the early 1960s new experiments were made in alternative production and distribution and breaking the hold over telling the story of the real, going further than protest to champion film culture over and above the commercial constraints and elitism of the industry to attempts at democratising. Carlo Lizzani’s Achtung! Banditi (1951) pioneered later attempts to break hegemonic distribution channels and the trade bias in favour of American imports. A cooperative was formed by filmmaker and viewers to produce and share its takings. De Sica and Visconti produced and funded themselves the masterpieces no one wanted to finance. Achtung! Banditi was also important for succeeding in bringing the factory and the workers on to the screen. Cf. Gian Piero Brunetta, Il cinema neorealista italiano. Da 'Roma città aperta' a 'I soliti ignoti', (Bari: Editori Laterza, 2009), 137. Achtung! Banditi is built around the systematic looting of machinery and equipment by the retreating German army, sent back to Germany. It extended to the theft of prewar films from the national film archive and removal of cinecameras from Cinecittà. On censorship in Italy, see Virgilio Tosi, Quando il cinema era un circolo. La stagione d'oro dei cineclub (1945-1956), (Venice: Marsilio, 1999) and Mino Argentieri, La censura nel cinema italiano, (Rome: Editori Riuniti, 1974). This polarity emerges very forcefully in all the attempts at repression and near suppression of Neo-realism which began as soon as the Left was expelled from the united front government in 1947 and decisively after the electoral victory of the Right in 1948 and its hegemony in Italian affairs, both cultural and political, until the 1960s and 1970s. Internationally, Italy was, and still is, a buffer state, between the changing geopolitics of the Balkans and the West, aligned with the Anglo-American alliance. Direct and indirect governmental censorship, generally treated as a separate subject, served as a repressive negation of alternative spatial practice, denying the political opening up of physical and discursive spaces. On several occasions, directors, actors and others protested in the street against governmental censorship and favouritism towards US imports and the bias in internal distribution. In the 1960s, Zavattini carried out several experiments which brought together an on and off screen spatial practice, seeking to put in place a new politics of cinema. The Newsreel of Peace (1963), the collective documentary produced by Zavattini and funded by the Italian Communist party, was a ground breaking experiment in applying and extending Neo-realism to replace the fiction of hegemonic Italian newsreels of the era (La Settimana Incom), which turned current affairs into a "spectacle", as Guy Debord was to argue a few years later in The Society of The Spectacle, Translated by Donald Nicholson-Smith, (New York: Zone 
Books, 1994 [1967]). Alternative production was also an attempt to democratise access to filmmaking. Between 1967 and 1971 Zavattini launched the "free newsreels", an experiment in direct democracy in cinema, encouraging participative filmmaking, and using left wing cultural and political circles for alternative distribution, to break out and challenge the closed shop of industry. In 1968, when Zavattini, Pasolini and the Italian filmmakers' association (ANAC) interrupted the Venice Film Festival, this was more than a gesture of solidarity with students and workers in France (following the May protest at Cannes). It was the outcome of years of challenging the film industry's hold over the means of production and seeking a space for dialogical cinema.

${ }^{42}$ The location is referred to in the literature as the "Fosse Ardeatine". Sadly, with the exception of the shots of Mussolini after his death and display at Piazzale Loreto in Milan, Days of Glory is virtually ignored outside Italy, as well as being invisible in Italy. Yet it constitutes the first documentary film about the Italian Resistance, shot and filmed in the last months of the war and completed immediately after Germany's surrender and is an exceptional in many ways both as historical document and should be part of the canon at least in the history of documentary film. As Ansano Giannarelli has pointed out, this documentary is extremely important for two reasons: for containing exceptional documents about contemporary Italy during the last year of the Second World War, concerning the struggle by the Italian Resistance against the Germans who occupied the country after the Armistice of 8 September 1943 and secondly, because major Italian filmmakers were involved in filming and making it (Giuseppe De Santis, Marcello Pagliero, Umberto Barbaro, filmmaker and critic, and Luchino Visconti). Some of the sequences are filmed in synch sound which was very unusual at the time, as they were shot on location. Cf. Ansano Giannarelli, "Un documento della nostra storia civile e cinematografica" in Mario Serandrei, Giorni di gloria, edited by Laura Gaiardoni (Rome: Bianco e Nero, Scuola nazionale di cinema and Editrice il Castoro, 1998), 17-18.

${ }^{43}$ On the concept of "everyday life" cf. Henri Lefèbvre's three volumes, beginning with Henri Lefèbvre, The Critique of Ever Day Life, Vol. 1. Translated by John Moore, (London and New York: Verso, 1991).

${ }^{44}$ In this film the real city of Rome is uncovered or mapped for the viewer through the wandering of Antonio and his son Bruno in search of their stolen bicycle through Rome's administrative and public spaces and its less visible borgate or working class peripheral districts.

${ }^{45}$ On Neo-realist wandering, cf. Torunn Haaland, "Paths of Nomadic Wandering in Neorealist Film and Literature", in Bondanella (ed.), The Italian Cinema Book, 92-100. Haaland applies Gilles Deleuze's idea of nomadism, a development of the structure of non-linear rhizomatic thinking, to Neo-realism, concluding that its wandering is open-ended and exploratory revealing an attitude of enquiry towards the unknown, creating a film culture of reflection and new thought: "Antonio's trajectory outlines foundations for a cinema that, rather than signifying preestablished meanings, seeks to survey and map out 'realms that are yet to come"'. Haaland, 99.

${ }^{46}$ She also obtained improved transport and services.

${ }^{47}$ Mino Argentieri, interviewed by the author, Rome, Easter 2014. Elio Petri's research was published in book form as Elio Petri, Roma Ore 11 with a Preface and Introduction by Giuseppe De Santis and Cesare Zavattini (Milan and Rome: Edizioni Avanti!, 1956). Petri was a young press reporter whose interviews and surveys of the city districts of Rome formed the basis of the film's screenplay. The original research is labelled as "screenplay" (sceneggiatura) in the archives of the Centro Sperimentale di Cinema, Rome, but is in fact Petri's 223 typed page investigative dossier on people and the city of Rome, and far more extensive than the published book. The section about the city demonstrates the new approach discussed above. For example, I cite from the text: "Preliminary factual information about Campo Parioli. An area which is close to the the Parioli district. Originally, a military field for the Italian air force. It is a shanty town, near a POW camp, and near Villa Glori." Petri goes on to say that: "most of the inhabitants are former DPs from the Lazio area. Some moved there in 1947 or 1948, but some had been living there from much earlier; many from after WWI. When a road was built crossing the area and requiring the demolition of some of the shacks, the dwellers were moved out and promised new accommodation. They got huts which were even worse than the ones they lived in already. Measuring 4 x 5 metres each room and each accommodating 6 people, after spending time being left to live outdoors with no roof over their head. (p. 102). Campo Parioli is only lit up at night when the lights reflect the light from the nearby Villa Glori and from cars driving from Ponte della Libertà. On 6 June, 3 families are being evicted, due to the construction of a new car park. Petri looked to see if any typists lived in this district, in vain." (p. 104). Petri found only one, who was helped to get to work by a young man with a truck who gave her a lift each day into town. "Campo Parioli is surrounded by beautiful houses." (p. 105). (Author's translation). Tellingly, the filmmaker was not allowed to film Campo Parioli, because it would have shown Rome in a negative light, because this would have shown the class clash or urban contradictions of a bidonville right next to a middleclass area. 
${ }^{48}$ The treatment was published even earlier, in Cinema, V 102 (25 September 1940) and signed by Antonio de Curtis, better known as the comic actor Totò and Cesare Zavattini. (Cf. Cesare Zavattini, Uomo, vieni fuori! Soggetti per il cinema editi e inediti, edited by Orio Caldiron (Rome: Bulzoni, 2006) 80). The novel first appeared in weekly instalments in Tempo in 1942 and in book form the following year. Cf. also Gualtiero De Santi, Ritratto di Zavattini scrittore, (Reggio Emilia: Aliberti editore, 2006), 159-173.

49 "Totò il Buono (1940)" in Zavattini, Uomo vieni Fuori!, 75. Author's translation.

${ }^{50}$ Zavattini, "Alcune Idee sul cinema", in Neorealismo ecc., 131, 97. NB. The second sentence occurs earlier in the text. In an article written in June 1952 and published in May 1953, Zavattini describes shadowing in these terms: "Neo-realism not only chooses a real worker for the role of a peasant, a real factory worker for the worker role, a real street in preference to a cardboard one, but instead of imaginary stories, choosing those events that take place before our very eyes, follow them, shadow them, with the patient optimism of someone who is aware that every point in space and time inhabited by mankind is important and can be told." Zavattini, "Il neorealismo continua", in Zavattini, Neorealismo ecc., 92. Zavattini, "Tesi sul neorealismo" in Neorealismo ecc., 115. "The concept of cohabitation" tied up with the principle of "shadowing" the real, is explained in "Tesi sul neorealismo" where Zavattini says: "filmmakers need to look at the real through c-habitation with it. The need for co-habitation may arise from ancestral experiences; but for us screenwriters and directors what matters is to establish meaningful relations with other people and with the real; so much so as to create new relations of artistic production which impacts on our art, but also on our lives, so as to generate a deeper contact with each other. Few are endowed with the patience to observe and to listen. Yet, even a gesture, or a word is enough to change a relationship." Zavattini, "Tesi sul neorealismo" in Neorealismo ecc., 114.

${ }^{51}$ This pioneering six-episode inquiry film with a prologue, an unattributed seventh episode lasting over eight minutes, accompanied by a voice-over opens which states a programmatic concern with the real made explicit through the rejection by words and images of escapist mainstream cinema. The first three minutes of commentary accompanied by photographs (marking the space of everyday life, the working class Italian extended family, the market and the factory at the close of day) is followed by extremely short sequences of couples desiring, quarrelling, being unfaithful, splitting up, and finding out about pregnancy. This material forms a framework supporting the work of the six authors.

52 The order of episodes in the title credits are at odds with the actual order of the film which might explain why in Bazin's "Neorealism Returns: Love in The City" a scene which belongs to the first eight minutes is credited as Dino Risi's Heaven For Three Hours (which, incidentally, is entirely filmed on location in Via San Giovanni in Laterano, nowhere near the Lungotevere of the still in the article). André Bazin, Le néo-réalisme se retourne: L'Amour à la ville", Cahiers du cinéma 12, 69 (March 1957) translated as "Neorealism Returns: Love in the City" in Bert Cardullo (ed. and trans.), André Bazin and Italian Neorealism (London and New York: Continuum), 2011, 187-191, 188. The boxed section "Our Investigations" (Le Nostre Inchieste) in the sequence of the actual film is preceded by Carlo Lizzani's Paid Sex, but on the credits page the order is reversed. The actual order is: 1. unacknowledged, 2. Carlo Lizzani, 3. Michelangelo Antonioni, 4. Dino Risi, 5. Federico Fellini, 6. Cesare Zavattini and Citto Maselli, 7. Alberto Lattuada.

${ }^{53}$ Lynch produces what he calls "a mental image of the city". (Kevin Lynch, The Image of The City,(Massuchussetts: MIT Press, 1960) 2.). He translates the chaos of the city into a legible pattern. His intervention in town planning was to use this concept to rebuild the city as a liveable space. What makes him interesting, is that Lynch's study, his designs and writing took the city dweller's point of view, not the planner's or the architect's or speculator's. This translated into consultation through long interviews with the inhabitants of districts, to find out how they experienced the city. (Lynch, The Image of The City, 140.). He also used short interviews on the street asking people directions to the same chosen places. In addition, Lynch employed trained observers in the field (Lynch, 140).

${ }^{54}$ By 1951, nearly 7 percent of Italians were homeless, and an additional 22 percent lived without adequate sanitation, according to Peter Rowe. Peter G. Rowe, Civic Realism (Cambridge, MA: MIT Press, 1997), 107 cited in Mark Shiel, "Cityscapes and Cinematic Space" in Peter Bondanella (ed.), The Italian Cinema Book (Basingstoke: Palgrave Macmillan, 2014), 89. According to a government report "Inchiesta sulla miseria", in 1951, there were over two million registered unemployed in Italy and a further four million "marginally employed", figures which are only an optimistic estimation of the reality with unemployment, including the industrial North as well as the rural South. Only a staggering 7.4 percent of Italian homes had drinking water, an inside toilet and electricity. Another cypher of poverty and unemployment is emigration: between 1946 and 1957, as many as 1,940,000 emigrated, of which 1,100,000 to the New World, and the remaining 840,000 to north Europe. Cf. Paul Ginsborg, A History of 
Contemporary Italy. Society and Politics 1943-1988 (London: Penguin, 1990), 187; 201; 211.

${ }^{55} \mathrm{Cf}$. Mark Shiel's excellent historical reconstruction of Mussolini's building programme in the above mentioned Shiel, Italian Neorealism. Rebuilding the Cinematic City, 2006 and Shiel, "Cinema and the City in History and in Theory" in Cinema and The City. Film and Urban Societies in a Global Context, 2001.

${ }^{56}$ There are also other lived spaces, in the brief episodes including ones about Catholicism and alternative forms of Christianity. But most of the film is about the contradictions of the city.

${ }^{57}$ Cf. Harvey, "Space as a Key Word" in: Spaces of Global Capitalism, 119-148.

${ }^{58}$ Both Chris Marker and Jean-Luc Godard have acknowledged that Italian Neo-realism brought ethics and politics into film, through an engagement with the everyday. This counters the philosophical approach of Theodor Adorno and Max Horkheimer in Dialectic of Enlightenment, trans. John Cumming (London and New York: Verso, 2008 [1944]). Godard still speaks of "the obligation to resist", something that only one film "did knowingly", he tells Youssef Ishagpour, his interviewer, Rossellini's Rome Open City (1945). (Jean-Luc Godard and Youssef Ishagpour, Cinema. The Archaeology of Film and The Memory of A Century (Oxford and New York: Berg, 2005, 94.).

Adorno's and Horkheimer's still influential approach was to claim the impossibility of any political dimension in art (or film seen as integral to the culture industry), other than as a refusal (harking back to Kant's aesthetics). For them, today's society is so inevitably dominated by the "culture industry" which uses instrumental reason to invade the workings of society, down to its very organisation. Therefore, the impact of capitalism transformed art into a commodity, a mass-produced object whose use value is equated with its exchange value for passive, alienated consumers, and geared exclusively to exploitation and entertainment. Thus, there can be no genuine art that is not 'autonomous' from society and its problems (a theory repeated in Adorno's later works). More recently, after the rising anti-capitalism of Seattle, the sociologist Pierre Bourdieu thought that writers, artists, and intellectuals could help to invent new ways of doing politics in the face of "novel dilemmas and threats of our age". (Pierre Bourdieu, Firing Back. Against the tyranny of the Market 2, Loïc Wacquant trans. (London and New York: Verso, 2003, 18.). For Bourdieu, art forms can have a symbolic power which can express critical ideas and analyses, by making visible and sensible the impact of neoliberal ideology. In The Future of The Image and other related writings, Jacques Ranciére takes a similar view and theorises it. He defines the artistic image as a set of operations or relations "between the sayable and the visible" and he calls this regime (or era defined by a specific intellectual paradigm), the "distribution of the sensible", partage du sensible a status quo which can be altered, through a redistribution, which creates new ways of seeing (Jacques Rancière, The Future of The Image, Gregory Elliott trans. (London and New York: Verso, 2007, 6.). That is how cinema can have purchase on the real.

\section{Bibliography}

Adorno, Theodor and Max Horkheimer. Dialectic of Enlightenment. Translated by John Cumming. London and New York: Verso, 2008 [1944].

Andrew, Dudley and Hervé Joubert-Laurencin eds. Opening Bazin: Postwar Film Theory and Its Afterlife. Oxford: Oxford University Press, 2011.

Argentieri, Mino. La censura nel cinema italiano. Rome: Editori Riuniti, 1974.

Badiou, Alain. The Theory of The Subject. Translated by Bruno Bosteels. London and New York: Continuum, 2009.

Badiou, Alain. The Century. Translated by and with a commentary by Alberto Toscano. Cambridge and Malden MA: Polity Press, 2007.

Bazin, André. What is Cinema, vol. 1. Translated by Hugh Gray. Berkeley: University of California Press, 1971.

Benjamin, Walter. "Theses on The Philosophy of History" in Illuminations edited by Hannah Arendt, translated by Harry Zohn. London: Fontana Press, 1992, 245-256. 
Bondanella, Peter (ed.). The Italian Cinema Book, Basingstoke: Palgrave Macmillan, 2014.

Bordwell, David. "The Art Cinema as a Mode of Film Practice" in Film Criticism, Vol. IV, 1 (1979) in The European Cinema Reader. Edited by Catherine Fowler. London and New York: Routledge, 2002, 94-102.

Bourdieu, Pierre. Firing Back. Against the tyranny of the Market 2, Translated by Loïc Wacquant. London and New York: Verso, 2003.

Brancaleone, David. "Zavattini: Reality and Illusion in Amore in Città and Siamo Donne”, Experimental Conversations 11 Spring (2013).

Brancaleone, David. http://www.experimentalconversations.com/articles/1175/zavattini-reality-andillusion-in-amore-in-citta/

Brancaleone, David. "Zavattini’s Kind of Documentary: Amore in Città and Its Seventh Episode”, Experimental Conversations, 11 Spring (2013). http://www.experimentalconversations.com/articles/1175/zavattini-s-kind-of-documentary-amore-incittal

Brunetta, Gian Piero. Il cinema neorealista italiano. Da 'Roma città aperta' a 'I soliti ignoti'. Bari: Editori Laterza, 2009.

Brunetta, Gian Piero. “Dal neorealismo al neorealismo?” in Antonio Vitti ed., Ripensare il neorealismo: cinema, letteratura, mondo. Pesaro: Metauro, 2008, 63-76.

Brunette, Peter. The Films of Michelangelo Antonioni. Cambridge: Cambridge University Press, 1998.

Butler, Judith. Frames of War. When is Life Grievable? London and New York: Verso, 2010.

Capello, Mario. (ed.) La fatica delle mani. Scritti su Vittorio De Seta. Milan: Feltrinelli, 2008.

Cardullo, Bert. (ed. and trans.), André Bazin and Italian Neorealism. London and New York: Continuum, 2011.

Cavell, Stanley. The World Viewed. Reflections on The Ontology of Film, Enlarged Edition. Cambridge Mass. and London: Harvard University Press, 1979.

CIAM. La carta de Atenas. Editorial Contémpora. Argentina; and Mumford, Eric. The CIAM Discourse on Urbanism, 1928-1960. Cambridge: MIT Press. 2000.

Clarke, David B. (ed.). The Cinematic City, London and New York: Routledge. 1997.

Cosulich, Callisto. "I conti con la realtà" in Callisto Cosulich ed., Storia del cinema italiano, Vol. VII,1945/48. Venice: Marsilio and Edizioni Bianco e Nero, 2003.

Dawkins, Richard. The Selfish Gene (2 ed.). Oxford: Oxford University Press. 1989. 
De Baecque, Antoine. Camera Historica. The Century in Cinema. Translated by Ninon Vinsonneau and Jonathan Magidoff. New York: Columbia University Press, 2012 [2008].

Debord, Guy. The Society of The Spectacle. Translation by Donald Nicholson-Smith. New York: Zone Books, 1994.

De Martino, Ernesto. "Intorno a una storia del mondo popolare subalterno”, Società, 3 (September 1949), 411-435.

De Santis, Gualtiero. Ritratto di Zavattini scrittore, Reggio Emilia: Aliberti editore, 2006.

Donald, James. Imagining The Modern City. London: Athlone Press, 1999.

Forgacs, David. Rome Open City. London: British Film Institute, 2000.

Gandin, Michele. Il tetto Vittorio De Sica, Bologna: Cappelli, 1956.

Gardiner, Michael. E. Critiques of Everyday Life. London and New York: Routledge, 2000.

Giannarelli, Ansano. "Un documento della nostra storia civile e cinematografica" in Mario Serandrei, Giorni di gloria, edited by Laura Gaiardoni. Rome: Bianco e Nero, Scuola nazionale di cinema and Editrice il Castoro, 1998, 17-18.

Ginsborg. Paul. A History of Contemporary Italy. Society and Politics 1943-1988, London: Penguin, 1990.

Godard, Jean-Luc. “A Film-maker is also a Missionary: Roberto Rossellini” in Tom Milne and Jean Narboni eds, Godard on Godard. Translated by Tom Milne. New York and London: Da Capo Press, 1972.

Godard, Jean-Luc and Youssef Ishagpour. Cinema. The Archaeology of Film and The Memory of A Century. Oxford and New York: Berg, 2005

Gramsci, Antonio. Selections from the Prison Notebooks. Edited and translated by Quintin Hoare and Geoffrey Nowell-Smith. London: Lawrence and Wishart, 1971.

Haaland, Torunn. "Paths of Nomadic Wandering in Neorealist Film and Literature", in Bondanella, Peter (ed.). The Italian Cinema Book, Basingstoke: Palgrave Macmillan, 2014.

Halliwell, Stephen. The Aesthetics of Mimesis. Ancient Texts and Modern Problems. Princeton and Oxford: Princeton University Press, 2002.

Harvey, David. "Space as a Key Word” in: Spaces of Global Capitalism, Towards a Theory of Uneven Geographical Development. London and New York: Verso, 2006, 119-148.

Harvey, David. A Brief History of Neoliberalism. Oxford: Oxford University Press, 2005.

Harvey, David. Spaces of Hope. Edinburgh: Edinburgh University Press, 2000.

Jameson, Frederic. Postmodernism, or The Cultural Logic of Late Capitalism. London and New York: Verso, 1991. 
Kelly, Richard. The Name of this Book is Dogme 95. London: Faber and Faber, 2000.

Kracauer, Siegfried. Theory of Film. The Redemption of Physical Reality. Oxford: Oxford University Press, 1960.

Lefèbvre, Henri. The Critique of Ever Day Life, Vol. 1. Translated by John Moore. London and New York: Verso, 1991.

Lefèbvre, Henri. The Production of Space. Translated by Donald Nicholson-Smith. Oxford: Basil Blackwell, 1991.

Lynch, Kevin. The Image of The City. Cambridge Mass.: MIT Press, 1960.

MacCabe, Colin. "Bazin as Modernist" in Dudley Andrew and Hervé Joubert-Laurencin eds, Opening Bazin: Postwar Film Theory and Its Afterlife. Oxford: Oxford University Press, 2011.

Micciché, Lino. "Il lungo decennio grigio" in Giorgio Tinazzi and Bruno Torri eds, Patrie visioni. Saggi sul cinema italiano 1930-1980. Pesaro: Marsilio, 2010.

Minh-ha, Trinh T. Framer Framed. New York: Routledge, 1992.

Nowell-Smith, Geoffrey. Making Waves. New Wave cinemas of the 1960s. London and New York: Bloomsbury, 2013.

Nowell-Smith, Geoffrey. "From Realism to Neo-realism" in Theorizing World Cinema. Edited by Lúcia Nagib, Chris Perriam and Rajinder Dudrah. London and New York: I.B. Tauris, 2012, 147-159.

Petri, Elio. Screenplay, Roma Ore 11. Centro Sperimentale di Cinema archives. Rome, 1951.

Petri, Elio. Roma Ore 11 with a Preface and Introduction by Giuseppe De Santis and Cesare Zavattini. Milan and Rome: Edizioni Avanti!, 1956.

Rancière, Jacques. The Future of The Image. Translated by Gregory Elliott. London and New York: Verso, 2007.

Ruberto, Laura E. and Kristi M. Wilson eds. Italian Neorealism and Global Cinema. Detroit: Wayne State University, 2007.

Rushton, Richard. The Reality of Film. Theories of Filmic Reality. Manchester and New York: Manchester University Press, 2011.

Schoonover, Karl. Brutal Vision. The Neorealist Body in Postwar Italian Cinema. Minneapolis and London: University of Minesota Press, 2012.

Shiel, Mark "Cityscapes and Cinematic Space" in Peter Bondanella (ed.). The Italian Cinema Book, Basingstoke: Palgrave Macmillan, 2014, 84-91.

Shiel, Mark. Italian Neorealism. Rebuilding the Cinematic City. London: Wallflower Press, 2006. 
Shiel, Mark. "Cinema and the City in History and in Theory" in Cinema and The City. Film and Urban Societies in a Global Context. Edited by Mark Shiel and Tony Fitzmaurice. Oxford and Malden Mass.: Blackwell, 2001.

Traverso, Antonio. "Italian Neorealism and Brazilian Cinema" in Ruberto and Wilson. Italian Neorealism and Global Cinema, 165-186.

Tosi, Virgilio. Quando il cinema era un circolo. La stagione d'oro dei cineclub (1945-1956), Venice: Marsilio, 1999.

Vitti, Antonio, ed. Ripensare il neorealismo: cinema, letteratura, mondo. Pesaro: Metauro, 2008.

Williams, Raymond. "Cinema and Socialism" in Raymond Williams, The Politics of Modernism. Against the New Conformists. London and New York: Verso, 1989, 107-118.

Zavattini, Cesare. "Dicembre 1953" in Cinema Nuovo 31, 15 March 1954.

Zavattini, Cesare. Neorealismo ecc., edited by Mino Argentieri. Milan: Bompiani, 1979.

Zavattini, Cesare. Uomo, vieni fuori! Soggetti per il cinema editi e inediti, edited by Orio Caldiron. Rome: Bulzoni, 2006. 